\title{
Physics and family values
}

Quebec. In an attempt to make amends for the publication, in the Canadian Journal of Physics, of a work of amateur sociology that blamed feminism and working mothers for the moral failings of modern undergraduates, the National Research Council (NRC) of Canada is taking the unprecedented step of publishing a monograph of rebuttals to the thesis.

The offending article was written by professor at the University of Alberta, and appeared in June 1991 in a special issue of the journal devoted to the proceedings of the international conference on the Kinetics of Non-Homogeneous Processes in NonLinear Dynamics. Entitled "Kinetics of nonhomogeneous processes in human society: unethical behavior and societal chaos", the article consisted of Freeman's assertion that cheating had become more common among first- and second-year chemistry students, followed by his belief, derived from interviews with students, that they lacked traditional moral values because they had been neglected by their working mothers.

As editor of the conference issue, Freeman was able to place his article in the journal, but its publication also had the approval of the journal's regular editor, physicist Ralph Nichols of York University, Toronto. Bruce Dancik, editor-in-chief of NRC journals, saw it only after publication, and was outraged.

"It shouldn't have appeared. It wasn't science and didn't belong in a scientific journal", he said. "Anywhere along the way Gordon Freeman, a 62-year-old chemistry

it could have and should have been caught and wasn't. We published an apology about six months after the article appeared [but] after that we continued to get a lot of letters. Quite a few groups wanted us to reprint the journal without the offending article. That we refused to do, of course: we didn't want to rewrite history".

Critics deplored the fact there was no formal way for qualified social scientists to respond. Dancik's talks with the most persistent of them led to planning of a journal issue devoted to responses and rebuttals.

The monograph will appear next February in a format similar to the physics journal, and will contain articles by Pat Armstrong, chairman of the sociology department at York University (who calls the "so-called study" a joke); Margaret Eichler, professor of sociology in the Ontario Institute for Studies in Education; and Connie StarkAdamec, president of the Canadian Psychological Association. It will also include a selection of letters the journal has received, along with some editorial responses. It will be sent to the 5,000 institutional subscribers in Canada and to the 1,100 physicists who received the conference journal containing Freeman's article.

Freeman, meanwhile, seems pleased with his notoriety. He began appearing on radio talk shows after his article was published, and newspaper advice columnist Ann Landers published his letter to her. "I've touched a nerve, haven't I?" Freeman told a reporter.

David Spurgeon

\section{Squabbling over Australian science}

Sydney. As in other recent elections in the English-speaking world, science and science policy are poised to play an inconsequential role in the Australian federal elections, which must be held within the next few months. With neither the ruling Labor party nor the opposing Liberal-National coalition in a strong position, the Federation of Australian Scientific and Technological Societies (FASTS), the country's main science lobbying group, had hoped to gain some political influence, but by attacking the science minister it has managed only to chill relations between the government and the scientific community.

A paper issued in August by the Australian Science Ministry and billed as a major science policy statement was recently described as "underwhelming" in a leading article in the FASTS journal. The article, written by executive director David Widdup, went on to declare that Ross Free, the science minister, was living up to his nickname "agenda-free". Free responded by describing the FASTS board as "wimps", and repeating his earlier support for a "more

Ditta Bartels, the president of FASTS, has since apologized to Free, and acknowledged his efforts in persuading the federal government to retain a substantial research and development tax concession. But news of the retention of the tax concession had already been leaked to the media, and the only other identifiable initiative in the science ministry paper was for an additional policy emphasis on engineering.

A spokesman for Free said that the August policy statement was adequate and that no further utterances were planned. In the meantime, letters written to Free during the dispute indicated, according to the spokesman, that FASTS favoured the LiberalNational opposition and that the lobbying group had therefore lost all influence with the minister.

Mark Lawson representative" body to replace FASTS.

\section{Hughes looks east for next expansion}

Washington. Continuing its efforts to expand outside the United States, the wealthy Howard Hughes Medical Institute is weighing the idea of supporting researchers in the republics of the former Soviet Union and Eastern Europe. Purnell Choppin, the Hughes president, says that the institute is giving "very serious consideration" to establishing a five-year, \$14-million grants programme in nations of the ex-Soviet bloc.

The search for eligible researchers - a hard task in a research structure still dominated by the former Soviet academies and their bureaucracies - could begin early next year. It would mark Hughes' third expansion outside the United States in as many years. In 1991, Hughes issued grants to 24 researchers in Canada and Mexico, and this week it announced awards to another 29 scientists in the United Kingdom, Australia and New Zealand (see Nature 357, 101; 1992).

Choppin says the institute is at present discussing possible funding mechanisms with Russian scientists and with US agencies and science academies that have been working in the former Soviet Union. Until now, Hughes has resisted starting a grants programme in the area on the grounds that it would be too difficult to ensure that its rigorous scientific standards could be met.

But as an increasing number of Western organizations look towards Russian and Eastern European science, some techniques for picking the best researchers have started to emerge. Choppin says Hughes will be looking at such criteria as whether a scientist has published outside the Soviet Union, and in English - two factors that will simplify the review process, at least. The institute is also considering opening a small office in Russia to administer and monitor the programme.

Hurdles still remain, however. Choppin says that Hughes is still wrestling with such fundamental issues as Russian tax laws and the mechanics of transferring money into the region's rudimentary banking system. But if Hughes officials can work out the details during the next two months, they could get final approval for the new programme at the next Hughes trustees meeting in February.

Although the average grant in Hughes' international programme so far has been about $\$ 90,000-\$ 100,000$ a year per scientist, grants in the former Soviet Union and Eastern Europe would probably be smaller, but more numerous. According to some estimates, as little as $\$ 2,000$ a year will support a Russian researcher, although Choppin says that additional travel and equipment money is required for Russian researchers to keep up to Western standards. Even so, $\$ 14$ million can go a long way, and the new programme, if approved, could more than double the number of Hughes' international grants. Christopher Anderson 